\title{
Pemberdayaan Ekonomi Umat Hindu Melalui Peningkatan Kemampuan Kewirausahaan Di Banjar Tresna Astiti Karya Kabupaten Lombok Barat
}

\author{
I Putu Sugih Arta, Nengah Sukendri
}

Fakultas Ekonomi dan Bisnis, Sekolah Tinggi Agama Hindu Gde Pudja, Mataram

Kata Kunci: pemberdayaan, ekonomi umat hindu, kewirausahaan

\begin{abstract}
Abstrak: Pemberdayaan ekonomi umat Hindu di Desa Duman belum mendapat perhatian optimal, terutama dari aspek permodalan dan penanganan manajemen. Selama ini, daerah setempat masih menggunakan modal sendiri dari warisan yang diperoleh secara turun temurun dengan manajemen yang tak direncanakan dengan baik. Seiring dengan kemajuan ipteks, warisan berupa modal tanah tersebut semakin menyempit dan permasalahan manajerial yang komplek, sehingga kerapkali menimbulkan krisis pada ekonomi umat Hindu. Dalam upaya mengurangi akibat negatif yang ditimbulkan oleh krisis ekonomi umat Hindu, diinisiasi kegiatan pada masyarakat di Banjar Tresna Astiti Karya, Dusun Duman Indah, Desa Duman Kecamatan Lingsar Kabupaten Lombok Barat. Identifikasi awal menemukan potensi unggulan yaitu beberapa wanita hindu memiliki kemampuan di bidang kerajinan tangan tas dan sokasi anyaman dari bahan tali plastik. Permasalahannya, belum terbentuknya inkubasi kelompok ekonomi produktif. Solusinya,tim pengabdian membentuk kelompok pengrajin wanita yang diwadahi dalam UKM Widya Karya Duman dan diresmikan langsung keberadaannya oleh Kepala Desa Duman. UKM Widya Karya Duman dalam perkembangannya telah mampu memproduksi pesanan tempat penyimpanan dari anyaman (sokasi). Kegiatan ini diharapkan menjadi embrio program-program lain selanjutnya dan menginspirasi untuk dilakukan penelitian terapan dan meningkatkan pendapatan masyarakat.
\end{abstract}

\section{Korespondensi: artaiputusugih@gmail.com}

\section{PENDAHULUAN}

Pembangunan ekonomi masyarakat desa membutuhkan peran berbagai pihak untuk tujuan tercapainya kesejahteraan. Program dan implementasinya, diperoleh dari penerapan suatu sistem dan prosedur yang dapat dipertangungjawabkan kesahihannya. Baik implementasi melalui penerapan sistem secara bottom up maupun top down. Kedua alur implementasi program harus proaktif, sehingga percepatan pembangunan tercapai sesuai dengan target yang diharapkan. Dalam menentukan arah implementasi dibutuhkan konsep pemberdayaan. Pemberdayaan merupakan suatu proses sekaligus upaya untuk mendapatkan atau memberikan daya, kekuatan atau kemampuan kepada individu dan masyarakat lemah agar dapat mengidentifikasi, menganalisis, menetapkan kebutuhan dan potensi serta masalah yang dihadapi dan sekaligus memilih alternatif pemecahannya dengan mengoptimalkan sumber daya dan potensi yang dimiliki secara mandiri (Widjajanti, 2011).

Pembangunan itu sendiri merupakan suatu proses menggambarkan adanya pengembangan dimana didalamnya juga meliputi proses pertumbuhan ataupun perubahan dalam kehidupan bersama sosial dan budaya. Pemberdayaan masyarakat memiliki beberapa istilah, antara lain sebagai berikut. Pertama, pemberdayaan masyarakat merupakan suatu 
proses di mana masyarakat, khususnya mereka yang kurang memiliki akses ke sumber daya pembangunan, didorong untuk meningkatkan kemandiriannya di dalam mengembangkan perikehidupan yang dialami. Selama ini. Kedua, pemberdayaan masyarakat juga merupakan proses siklus terus-menerus, proses partisipatif di mana anggota masyarakat bekerja sama dalam kelompok formal maupun informal untuk berbagi pengetahuan dan pengalaman serta berusaha mencapai tujuan bersama. Jadi, pemberdayaan masyarakat merupakan suatu proses sedangkan tujuannya terbagi atas aspek membangkitkan partispasi penuh warga masyarakat dan tujuan akhir yaitu perwujudan kemampuan dan integrasi masyarakat untuk membangun diri mereka sendiri (Wibhawa, et al., 2010).

Pemberdayaan ekonomi umat Hindu, selama ini belum mendapat perhatian optimal. Terutama dari aspek permodalan dan penanganan manajemen. Menurut Putra (2015) berharap bahwa lebih banyak penelitian di bidang manajemen yang dapat dibahas dari ajaran Hindu seperti strategi manajemen, manajemen keuangan dan manajemen sumber daya manusia dapat dilakukan untuk penelitian mendatang.

Masyarakat Hindu di Pulau Lombok pada dasarnya masih menggunakan modal sendiri dari warisan yang diperoleh secara turun temurun dengan manajemen yang tak direncanakan dengan baik. Memang ada ada tujuh cara yang sah dalam memperoleh hak milik dalam ajaran Hindu yaitu pewarisan, hadiah persahabatan, pembelian, penaklukan, peminjaman dengan bunga, melakukan pekerjaan dan menerima hadiah dari orang-orang saleh (Putra,2015). Salah satu dari ketujuh hal tersebut adalah warisan, yaitu berupa modal tanah yang saat ini kondisi tanah tersebut semakin menyempit dan permasalahan manajerial yang komplek, sehingga kerapkali menimbulkan krisis pada ekonomi umat Hindu. Tujuan kegiatan pemberdayaan ekonomi umat Hindu dalam mewujudkan kesejahteraan melalui peningkatan kemampuan kewirausahaan di Banjar Tresna Astiti Karya Dusun Duman Indah Desa Duman Kecamatan Lingsar Kabupaten Lombok Barat.Tujuan dari pelaksanaan kegiatan ini adalah:

1. Mengetahui partisipasi penuh warga masyarakat dan tujuan akhir yaitu perwujudan kemampuan dan integrasi masyarakat untuk membangun diri untuk mencapai kesejahteraan melalui peningkatan kemampuan kewirausahaan.

2. Implementasi program yang dilaksanakan sebagai bentuk luaran pendampingan di Banjar Tresna Astiti Karya Dusun Duman Indah Desa Duman Kecamatan Lingsar Kabupaten Lombok Barat.

\section{METODE KEGIATAN}

Untuk menjawab permasalahan pertama maka dibutuhkan pendekatan kelompok yang dapat dipaparkan dalam pembahasan dimana kelompok sosial merupakan himpunan atau kesatuan manusia yang hidup bersama, karena adanya hubungan di antara mereka. Hubungan tersebut antara lain menyangkut hubungan timbal balik yang saling mempengaruhi dan juga suatu kesadaran untuk saling menolong (Soekanto, 2007). Kelompok juga dapat mempengaruhi lingkungan sosial dimana anggotanya yang saling tergantung satu sama lain dan setidak-tidaknya memiliki potensi untuk melakukan interaksi satu sama lain (Pratiwi et al., 2013). 
Kelompok primer di dalamnya itu terdapat interaksi sosial yang lebih intensi dan lebih erat antara anggotanya. Kelompok primer juga disebut face to face group yaitu kelompok sosial yang anggota-anggotanya sering bertatap muka satu sama lain dan saling mengenal dari dekat dan karena itu hubungannya lebih erat (Asnafiyah, 2008).

Kelompok disini dapat diklasifikasikan dari perspektif psikologi, dan juga sosiologi, adapun kelompok dapat diklasifikasi kedalam :

a. Kelompok Primer dan Kelompok Sekunder

b. In -group dan Out-group

c. Kelompok Keanggotaan dalam Kelompok Rujukan

d. Kelompok Deskritiptif dan Kelompok Preskiptif.

Idealnya sebuah kelompok terbentuk hendaknya memiliki hal sebagai berikut :

Otonomi

Otonomi dalam arti lain juga memiliki arti yang sama. Otonomi adalah pelimpahan hak, wewenang dan tanggung jawab pemerintahan atau otonomi yang luas dari Pemerintah Pusat kepada Pemerintah Daerah Kabupaten/Kota, dan Pemerintah Propinsi secara terbatas/lintaskabupaten/kota kecuali bidang-bidang Politik Luar Negeri, Hukum/Peradilan,Pertahanan dan Keamanan, Keuangan dan Moneter, dan Agama (An-Naf, 2006).

Komunitas yang baik salah satunya juga harus memiliki otonomi. Konsep otonomi desa adalah sebagaiadanya kemampuan serta prakarsa masyarakat desa untuk dapat mengaturdan melaksanakan dinamika kehidupannya dengan sedapat mungkindidasarkan pada kemampuannya sendiri dengan mengurangi intervensi pihakluar, berdasarkan wewenang yang dimilikinya dengan bersandar pada peraturan yang berlaku. Pemberlakuan kebijakan Otonomi Desa juga mengundang berbagai tanggapan serta pandangan baik itu dari pemerintahmaupun masyarakat, tentang dampak ataupun hal-hal yang ingin dicapai dari pemberlakuannya (Nadir, 2013).

Adapun tujuan dari otonomi daerah ataupun otonomi secara sederhana, yang pertama menjaga stabilitas politik dan dari sisi pelayanan memudahkan untuk pelayanan kepada publik, sedangkan yang kedua adalah upaya untuk mencapai kemandirian peningkatan kehidupan bermasyarakat (Madani, 2006).

Viabilitas

Viabilitas atau problem solving merupakan salah satu indikator dalam menentukan komunitas yang baik.Viabilitas memiliki arti keyakinan bahwa masyarakat memiliki kemampuan untuk memecahkan masalahnya sendiri. Hal ini merupakan hak menentukan keputusan-keputusan yang mempengaruhi kesejahteraan mereka (Aziz, et al., 2005).Metode pemecahan masalah (Problem Solving) adalah penggunaan metode dalam kegiatan pembelajaran dengan jalan melatih peserta didik menghadapi berbagai masalah baik itu masalah pribadi atau perorangan maupun masalah kelompok untuk dipecahkan sendiri atau secara bersama-sama. Metode Problem Solving bukan hanya sekedar metode mengajar, tetapi juga merupakan suatu metode berfikir, sebab dalam metode Problem Solving dapat menggunakan metode-metode lainnya yang dimulai dengan mencari data sampai pada menarik kesimpulan (Djamarah dan Zain, 2006). 


\section{Distribusi kemampuan yang merata}

Setiap orang berkesempatan yang sama dan bebas menyatakan kehendaknya (Roesmidi dan Risyanti, 2006). Kekuasaan seseorang dalam suatu masyarakat berhubungan dengan besarnya pengaruh orang tersebut terhadap orang-orang yang ada di sekitarnya. Sedangkan orang yang tidak mempunyai kekuasaan, seperti buruh tani akan menempati kedudukan yang rendah. Sumber kekuasaan tidak pernah terdistribusikan secara merata dalam setiap masyarakat atau sistem politik. Sumber daya manusia merupakan modal yang sangat penting dalam melakukan pembangunan. Keterkaitan masalah ini dengan pemberdayaan masyarakat sangat besar (Sitepu, 2010).

Dampak pemberdayaan masyarakat adalah kemandirian masyarakat dalam mengatasi permasalahan mereka melalui prakarsa dan kreatifitas untuk meningkatkan kualitas hidup. Kemandirian tentunya membutuhkan masyarakat yang mempunyai pengetahuan, ketrampilan dan sikap untuk keluar dari permasalahan mereka(Sitepu, 2010).

Kesempatan Setiap Anggota Masyarakat untuk Berpartsipasi Aktif untuk Kepentingan Bersama Memberi Kesempatan Aktif kepada Anggota Masyarakat

Partisipasi diartikan sebagai keterlibatan setiap warga negara yang mempunyai hak dalam pembuatan keputusan, baik secara langsung maupun melalui intermediasi institusi legitimasi yang mewakili kepentingannya, partisipasi masyarakat merupakan kebebasan dan berbicara dan berpartisipasi secara konstruktif. Sementara Partisipasi masyarakat adalah keikutsertaan masyarakat dalam proses pengidentifikasian masalah dan potensi yang ada di masyarakat, pemilihan dan pengambilan keputusan tentang alternatif solusi untuk menangani masalah, pelaksanaan upaya mengatasi masalah, dan keterlibatan masyarakat dalam proses mengevaluasi perubahan yang terjadi (Isbandi, 2007).

Partisipasi yang berlaku secara universal adalah sebagai kerja sama antara rakyat dan pemerintah dalam mengembangkan hasil pembangunan (Muslim, 2007). Partisipasi yang didorong oleh mental dan emosi yang demikian itu, disebut sebagai partisipasi "sukarela". Sedangkan partisipasi dengan paksaan disebut mobilisasi. Partisipasi mendorong orang untuk ikut bertanggung jawab di dalam suatu kegiatan, karena apa yang disumbangkannya adalah atas dasar kesukarelaan sehingga timbul rasa bertanggung jawab kepada organisasi.Partisipasi masyarakat merupakan proses yang menyediakan kesempatan bagi individu untuk mempengaruhi keputusan publik dan telah lama menjadi komponen dari proses pengambilan keputusan yang demokratis Dalam pengambilan keputusan yang teknokratis, masyarakat diasumsikan tidak memiliki hak untuk berpartisipasi (Aswanah, 2013).

Proses ke dalam, pada lingkungan tradisi patisipasi dapat pula mendorong terjadnya komodifikasi yaitu transformasi hubungan yang sebelumnya bersih dari perdagangan, menjadi hubungan komersial, hubungan pertukaran, membeli dan menjual (Arta, 2017)

\section{Adanya Heterogenitas}

Heterogenitas atau beda pendapat merupakan ciri indicator komitas yang baik. Dalam proses pembangunan masyarakat dibutuhkan suatu komunitas yang baik. Karena pembangunan masyarkat bertujuan untuk pembentukan masyarakat yang memiliki 
kemampuan yang memadai untuk memikirkan dan menentukan solusi yang terbaik dalam pembangunan tentunya tidak selamanya harus dibimbing, diarahkan dan difasilitasi (Sulistio, 2012).

Pemberdayaan tidak bersifat selamanya, melainkan sampai target masyarakat mampu untuk mandiri, dan kemudian dilepas untuk mandiri, meskipun dari jauh tetap dipantau agar tidak jatuh lagi. Namun pemberdayaan hanya terjadi pada suatu masa proses belajar, hingga mencapai status mandiri. Proses pemberdayaan masyarakat semestinya juga didampingi oleh suatu tim fasilitator yang bersifat multidisiplin (Mubarak, 2010). Dalam proses pemberdayaan masyarakat, adanya heterogenitas menyebabkan tingkat pendapatan pada suatu komonitas masyarkat tidak lagi menjadi tolak ukur utama dalam menghitung tingkat keberhasilan pembangunan (Elmubarok, 2008).

\section{Manajemen Konflik}

Manajemen Konflik adalah suatu cara atau proses mengambil langkah-langkah oleh para pelaku atau pihak ketiga dalam rangka mengarahkan perselisihan ke arah hasil yang positif dengan melakukan pendekatan, komunikasi dan evaluasi untuk mendapatkan penyempurnaan untuk mendukung tujuan yang telah ditetapkan. (Winardi, 2007). Manajemen Konflik merupakan langkah yang dapat digunakan individu atau kelompok untuk menghadapi pertentangan atau perselisihan yang terjadi di dalam kehidupan.Manajemen konflik menjadi suatu kajian yang penting untuk dipelajari dan dipahami dalam meyelesaikan potensi konflik atau konflik itu sendiri, sehingga menghasilkan kesamaan sudut pandang (perception) dan kepentingan (interest) (Karimah, 2014).

Dari konsep pendekatan kelompok diatas, warga Banjar Tresna Astiti Karya Dusun Duman Indah Desa Duman Kecamatan Lingsar Kabupaten Lombok Barat secara umum potensi dasar dalam upaya peningkatan kesejateraan mereka bermata pencaharian buruh tani dan pedagang. Disamping itu, beberapa warga mempunyai kemampuan kreatif dalam bidang home industri kerajinan membuat anyaman tas, sok asi (bakul tertutup) dari tali plastik. Kemampuan ini semestinya diberdayakan dalam bentuk kelompok, namun mereka belum meliki kesadaran dan kemampuan akan pentingnya suatu kelompok usaha bersama.

\section{HASIL DAN PEMBAHASAN}

Program Penyuluhan Kewirausahaan dan Pembentukan KUBE.

Kegiatan pendampingan yang dilaksanakan dari tanggal 23 Maret 2019 s/d 27 Maret 2019 dengan materi inti Penyuluhan Kewirausahaan dan Pembentukan KUBE UKM Widya Karya dimana pengurusnya dilantik oleh Kepala Desa Duman. 

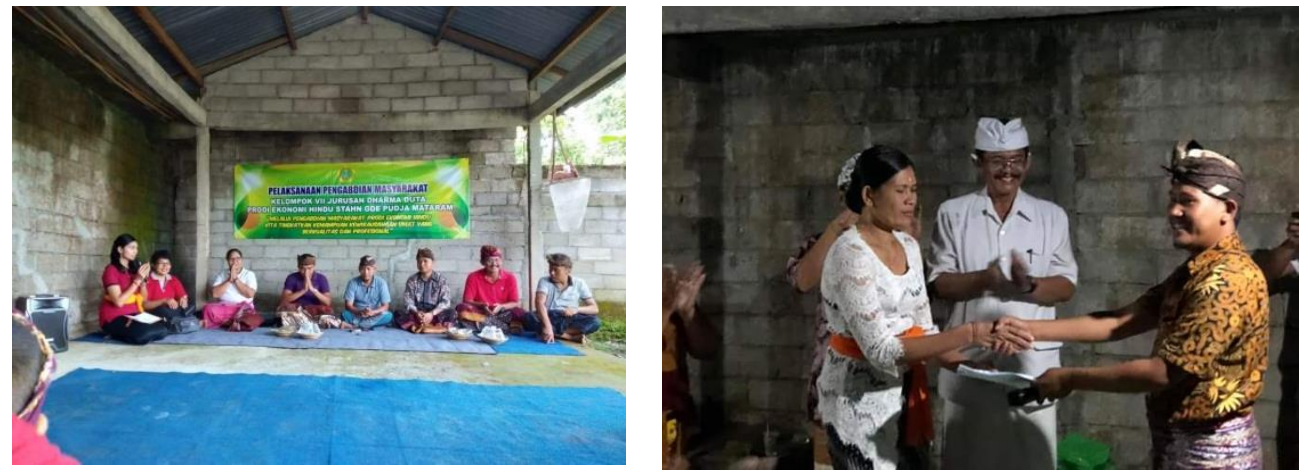

Gambar 1. Pengabdian Masyarakat di Desa Duman Kecamatan Lingsar

Berdasarkan analisis situasi dan permasalahan yang dihadapi, diberikan suatu solusi untuk mengatasi kesulitan yang dialami masyarakat. Permasalahan utama, belum menyadari pentingnya kelompok kewirausahaan bagi para pengrajin dalam mencapai tujuan bersama. Program UKM merupakan program usaha kecil menengah, yaitu kelompok industri modern, industri tradisional dan industri kerajinan yang mempunyai investasi modal untuk mesinmesin dan peralatan sebesar Rp.70 juta ke bawah dengan resiko investasi modal tenaga kerja Rp. 625.000 ke bawah dan usahanya dimiliki oleh Warga Negara Indonesia.

Pemahaman secara teknis kelompok usaha dibutuhkan penyuluhan bagi masyarakat sebagai bentuk transfer ipteks. Dengan harapan luaran pengabdian adalah terbentuknya kelompok usaha (UKM) yang disahkan keberadaannya oleh Kepala Desa Duman sebagai penguasa wilayah setempat. Desain mengatasi permasalahan bagi mitra adalah sebagai berikut :

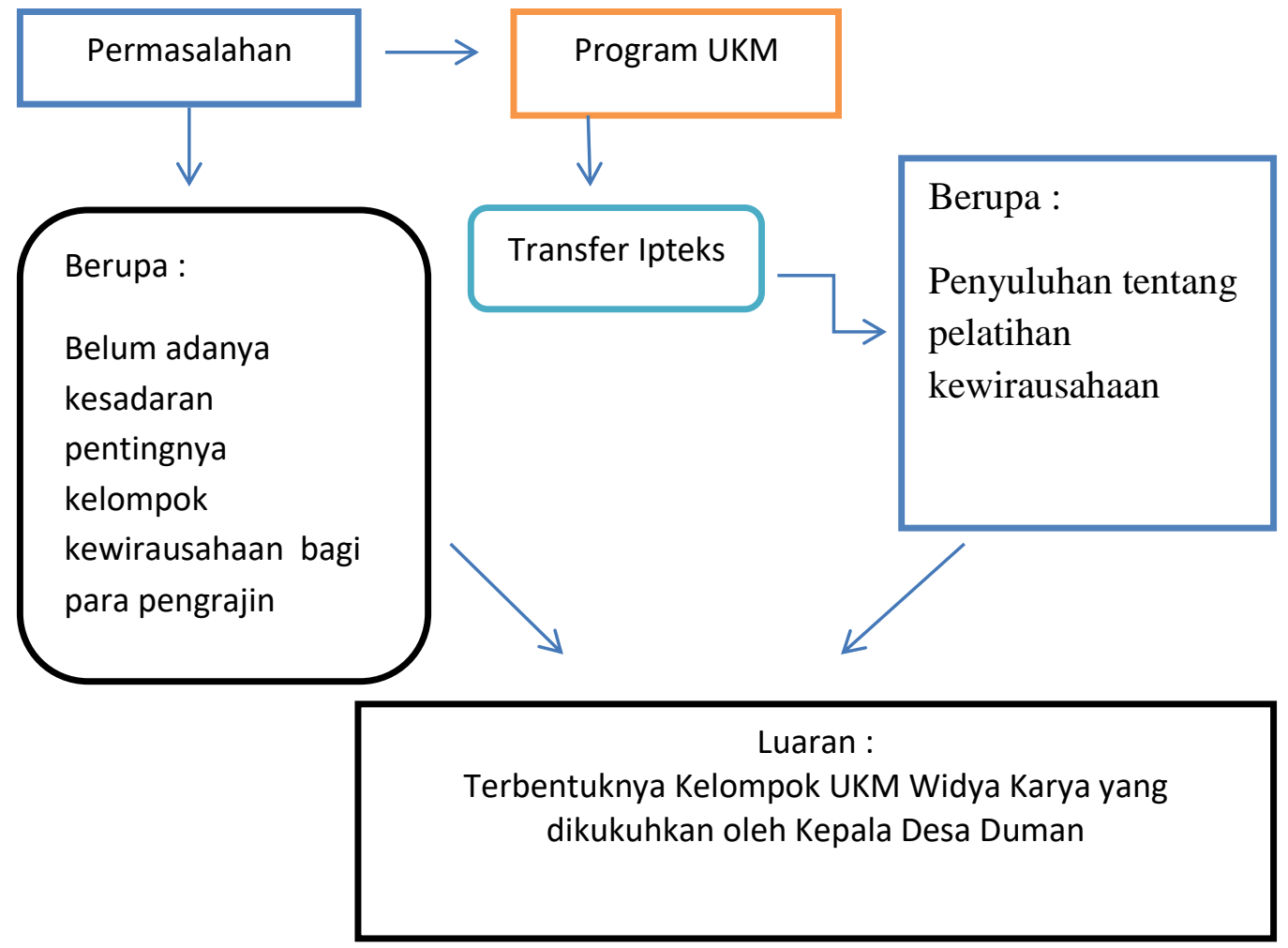

Gambar 2. Desain mengatasi permasalahan 
Keterlibatan mahasiswa dalam kegiatan ini akan lebih mempermudah dan mempercepat pencapaian tujuan yang diinginkan. Solusi yang ditawarkan kepada mitra adalah dengan transfer iptek berupa penyuluhan yang berkaitan dengan pentingnya kelompok usaha bersama dalam meningkatkatkan kesejateraan melalui kewirausahaan serta dilakukan pendampingan kepada pihak mitra. Sampai terbentuknya kelompok tersebut.

\section{KESIMPULAN DAN SARAN}

Kesimpulan

1. Partisipasi Warga Banjar Tresna Astiti Karya Dusun Duman Indah Desa Duman Kecamatan Lingsar Kabupaten Lombok Barat yang mayoritas beragama Hindu belum maksimal, yaitu belum semua memiliki kesadaran yang sama untuk membuat kelompok usaha. Idealnya kelompok usaha yang terbentuk memiliki otonomi, viabilitas, distribusi kemampuan, partisipasi aktif, hetrogenitas dan manajemen konflik dari para anggotanya dalam pencapaian tujuan organisasi.

2. Implementasi program pendampingan yang dilaksanakan untuk membantu memecahkan kesulitan warga melalui pembuatan desain, mengatasi permasalahan, sampai terwujudnya dan dilantiknya pengurus UKM Widya Karya Duman oleh Kepala Desa Duman. Inisiasi Kelompok Usaha Bersama (KUBE) dalam mewujudkan kesejahteraan melalui peningkatan kemampuan kewirausahaan maka dibutuhkan pelatihan kewirausahan.

Saran

1. Untuk melaksanakan Tri Dharma Perguruan Tinggi terutama pengabdian masyarakat dibutuhkan perencanaan yang kuat, sebagai tolok ukur pencapaian target yang ditetapkan sehingga membutuhkan pertemuan intens berbagai pihak yang berkepentingan dari berbagai unsur seperti Muspida, Perguruan Tinggi, Toga dan Toma.

2. Pengabdian ini diharapkan menjadi embrio pengabdian selanjutnya dan tidak menutup kemungkinan menjadi inspirasi dosen ekonomi melakukan penelitian terapan.

\section{DAFTAR PUSTAKA}

Arta, I. Putu Sugih. "KOMODIFIKASI TRADISI MEGIBUNG DI LOMBOK." Widya Katambung 8, no. 1 (2017).

An-Naf, J. 2006. Memahami Beberapa Potensi Masalah Dalam Proses Otonomi Daerah. Jurnal Madani. 1 (1): 1-2.

Asariansyah M F, Choirul S, Stefanus P R. 2013 . Partisipasi Masyarakat Dalam Pemerataan Pembangunan Infrastruktur Jalan (Studi Kasus Di Kecamatan Lawang Kabupaten Malang). Jurnal Administrasi Publik (Jap). 1(6): 1141-1150.

Asnafiyah. 2008. Kelompok Keagamaan dan Perubahan Sosial (Studi Kasus Pengajian IbuIbu Perumahan Purwomartani). Jurnal Aplikasi llmu-ilmu Agama. IX (1):1-16.

Elmubarok, Z. 2008. Membumikan Pendidikan Nilai. Alfabeta. Bandung.

Griffin. 2005. Pengantar Manajemen. Erlangga. Jakarta.

Hasibuan. 2006. Manajemen Dasar, Pengertian dan Masalah. Bumi Akasara, Jakarta.

Putra, I.N.N.A, 2015. Riba dan Pembiayaan dalam Konsep Hindu, Jurnal Keuangan dan Perbankan, 19 (3): 488-496. 
Shofiyah.2011. Persepsi Masyarakat Terhadap Pelaksanaan Fungsi Kepala Desa Sebagai Opinion Leader Di Desa Pewunu Kec. Dolo Barat Kab. Sigi. Jurnal Academica Fisip Untad. 3 (1): 564-575.

Siswanto, H.B.2011. Pengantar Manajemen. BumiAksara. Jakarta.

Widjajanti, K. 2011.MODEL PEMBERDAYAAN MASYARAKAT. Jurnal Ekonomi Pembangunan. 12 (1). hlm.15-27.

Winardi. 2007.Manajemen Konflik. Mandarmaju. Bandung. 